\title{
Surgical outcome of genito-urinary obstetric fistulas (GUOF) with or without bladder neck involvement: an experience from the University Teaching Hospital, Yaoundé, Cameroon
}

\section{Summary}

Surgical Outcome of Genito-urinary obstetric fistulas (GUOF) with or without bladder neck involvement: an experience from the University Teaching Hospital, Yaounde, Cameroon

Introduction: The GUOF is a solution of continuity between the genital tract and the urinary tract in connection with pregnancy or childbirth. The urethral involvement seems to be associated to a bad prognosis. However, little is known about this issue.

Objective: To analyze the result of post-surgical GUOF with or without urethral involvement.

Methodology: It was a retrospective cohort study. We identified the files of the patients with or without urethral involvement operated at the department of Obstetrics \& Gynecology of UTH, Yaounde from March 03, 2009 to March 03, 2015 (six years). Data was collected from the files, registers, and by phone call from the participants after oral consent. Variables included the sociodemographic, clinical and therapeutic patterns. Data was analyzed using EPI-Info 7.1 software. We compared the data of patients with GUOF or without urethral involvement. A difference was considered significant if $\mathrm{P}<0.05$.

Results: We analyzed the data of 92 GUOF patients, $23(25.0 \%)$ with urethral involvement and 69 without. The fistulas with urethral involvement were more likely to have large size of more than $4 \mathrm{~cm}(30 \% \mathrm{vs} 10 \%)$, and to have a major fibrosis ( $39 \%$ vs $3 \%$ ). Also, fistulas with urethral involvement were more at risk to have undergone more previous repairs $(69.5 \%$ vs $17.4 \%$; OR: $11.11 ; 95 \%$ CI $[5.0$ to 33.33$]$; $\mathrm{P}=0$, 000007). In the urethral involvement group, the surgical technique had often been plastic surgery $(52.2 \%$ vs $17.4 \%$; OR, $5.8 ; 95 \%$ CI [ 1.85 to 14.48$]$; $\mathrm{P}=0.002)$. The patients without urethral involvement had the best results in terms of continence with closure at the end of 3 months ( $81.2 \%$ vs $30.4 \%$; OR: 9.84 ; $95 \%$ CI to [3.36 to 28.8 ] $\mathrm{P}=0.000014)$.

Conclusion: GUOF with urethral involvement were fibrous with large size. The rate of closure with continence was less satisfactory in case of urethral involvement.
Volume 10 Issue 3 - 2019

\author{
Pierre Marie Tebeu, ${ }^{1-4}$ Michel Ekono, ${ }^{5}$ Claude \\ Cyrille Noa Ndoua, ${ }^{2}$ Georges Didier Ngassa \\ Meutchi, ${ }^{3}$ Yvette Nkene Mawamba, ${ }^{4}$ Charles- \\ Henry Rochat ${ }^{6}$ \\ 'Inter-States High School for Public Health Training of Central \\ Africa (CIESPAC), Congo \\ ${ }^{2}$ Faculty of Medicine and Biomedical Sciences, University of \\ Yaoundé I, Cameroon \\ ${ }^{3}$ League for Initiative and Active Research for Women's Health \\ and Education (LIRASEF), Cameroon \\ ${ }^{4}$ Department of Gynecology Obstetrics, University Teaching \\ Hospital,Yaoundé-Cameroon

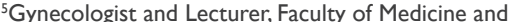 \\ Pharmaceutical Sciences, University of Douala, Cameroon \\ ${ }^{6} \mathrm{Geneva}$ Foundation for Medical Education and Research, \\ Switzerland
}

\begin{abstract}
Correspondence: Prof. Pierre Marie Tebeu Marie, MD.MPH, Inter-States High School for Public Health Training of Central Africa (CIESPAC), Congo, Tel 237677675533
\end{abstract} Email pmtebeu@yahoo.fr

Received: May 29, 2019 | Published: June 25, 2019

Keywords: obstetric fistulas, post-surgical, urethral involvement, Cameroon

\section{Introduction}

Obstetric fistula (OF) is a continuity between the urinary tract and the vagina (vésico-vaginal fistula) or between the rectal tract and vagina (recto-vaginal fistula). ${ }^{1,2} \mathrm{OF}$ usually occurs after prolonged and difficult labor in the absence of appropriate obstetric care to remedy it. $^{3-8}$ Fistula can be urethral, cervical, trigonal, retro-trigonal or juxtacervical according to the location on the urinary tree. ${ }^{9,10}$ Surgical results of genitourinary fistula are diversely reported, with cure rate of $46 \%$ to $95 \%{ }^{11-15}$ WHO suggests for the first surgical attempt, an expected closure of $85 \%$ with $90 \%$ of continence among closed cases. ${ }^{15}$

This suggestion only takes into account the past surgical history, but not anatomical features of the fistula (location, size, fibrosis). ${ }^{16-18}$ Some studies reported prognostic value of urethral location and the fistula increased failure risk in case their involvement. ${ }^{19,20}$ Success of
$57 \%$ was reported for cervico-urethral location and $79 \%$ for bladder body involvement. ${ }^{21}$ Little data exists on the prognosis of obstetric fistula with urethral involvement in Cameroon.

Objective: Analyze post-surgical outcome of genitourinary obstetric fistula with or without urethral involvement.

\section{Methodology}

This was a retrospective cohort study in the University Teaching Hospital, Yaounde on GUOF patients operated from 03 March 2009 to 3 March 2015 (six years). We considered obstetric fistula with urethral involvement "subject group" and obstetric fistula without urethral involvement "control group". Patient's files were reviewed, we excluded non-obstetric, genitourinary digestive and vesico-uterine cases. After an oral consent, we collected data through registers, 
patient files and telephone contact. We considered socio-demographic variables (age, occupation, residence, marital status, educational level). Clinical and reproductive characteristics of interest were antenatal care, delivery, perinatal and fistula surgery characteristics. Data was analyzed using EPI-Info7.1. Proportions, means or median were calculated. Variables were compared among the two study populations using $\mathrm{Ch}^{2}$ test. Odds ratio (OR) with $95 \%$ confidence interval (CI) was used to assess the influence of the urethral location on the fistula outcome. The level of significance was set at $\mathrm{p}<0.05$.

\section{Results}

Over a period of 6 years, we identified 102 files of GUOF at the UTHY among which we eliminated 3 files of vesico-uterine fistula, 3 ureteral fistula and 4 files of deceased patients. We retained 92 files of GUOF patients including 23 with urethral damage and 69 without urethral. Primary level of education was the most represented (54.3\%), almost equal distribution between subjects (52.2\%) and control (55.1\%). Many patients had no occupation (77.2\%) and were more from a rural area of residence $(57.6 \%)$. Cameroonians from the western region were the most represented in the two study groups (30.4\%) followed by the center region (25\%). Single parity status was more common in the urethral location group (69.6\% versus $47.8 \%)$ (Table 1).

Table I Patient's socio-demographic characteristics according to fistula location

\begin{tabular}{|c|c|c|c|c|}
\hline \multirow[b]{2}{*}{ Characteristics } & \multicolumn{3}{|c|}{ Fistula with urethral location } & \multirow[b]{2}{*}{ P-Value } \\
\hline & $\begin{array}{l}\text { Yes } \\
N I=23 \\
n I(\%)\end{array}$ & $\begin{array}{l}\text { No } \\
\text { N2=69 } \\
\text { nI (\%) }\end{array}$ & $\begin{array}{l}\text { Total } \\
\mathrm{N}=92 \\
\mathrm{n}(\%)\end{array}$ & \\
\hline \multicolumn{5}{|l|}{ Age groups } \\
\hline $15-19$ & $6(26)$ & $18(26)$ & $24(26)$ & \multirow{3}{*}{0.2701} \\
\hline $20-34$ & $16(69.6)$ & $4 \mid(59.4)$ & $57(62)$ & \\
\hline $35-45$ years & I (4.3) & $10(14.5)$ & II (I2) & \\
\hline \multicolumn{5}{|l|}{ Educational level } \\
\hline Primary & $12(52.2)$ & $38(55.1)$ & $50(54.3)$ & \multirow{3}{*}{0.4985} \\
\hline Secondary & II (47.8) & $28(40.6)$ & $39(42.4)$ & \\
\hline Higher & $0(0)$ & $3(4.3)$ & $3(3.3)$ & \\
\hline \multicolumn{5}{|l|}{ Marital status } \\
\hline Married & $8(34.8)$ & $21(30.4)$ & $29(31.5)$ & \multirow{3}{*}{0.5947} \\
\hline Single & $15(65.2)$ & $45(65.2)$ & $60(65.2)$ & \\
\hline Widow & $0(0)$ & $3(4.3)$ & $3(3.3)$ & \\
\hline \multicolumn{5}{|l|}{ Profession } \\
\hline Public sector & $2(8.7)$ & $2(2.9)$ & $4(4.3)$ & \multirow{4}{*}{0.1005} \\
\hline Private sector & I (4.3) & $3(4.3)$ & $4(4.3)$ & \\
\hline Housewife & $15(65.2)$ & $56(8 \mid .2)$ & $7 \mid(77.2)$ & \\
\hline Student & $5(21.6)$ & $8(11.6)$ & $13(14.2)$ & \\
\hline \multicolumn{5}{|l|}{ Ethnic group } \\
\hline Bantu & $12(52.2)$ & $40(58)$ & $52(56.5)$ & \multirow{3}{*}{0.4023} \\
\hline Semi-Bantu & $9(39.1)$ & $24(34.8)$ & $33(35.9)$ & \\
\hline Sudanese & $2(8.7)$ & $5(7.2)$ & $7(7.6)$ & \\
\hline
\end{tabular}

\begin{tabular}{|c|c|c|c|c|}
\hline \multicolumn{5}{|c|}{ Fistula with urethral location } \\
\hline \multirow[t]{2}{*}{ Characteristics } & $\begin{array}{l}\text { Yes } \\
N I=23\end{array}$ & $\begin{array}{l}\text { No } \\
\text { N2=69 }\end{array}$ & $\begin{array}{l}\text { Total } \\
\mathrm{N}=92\end{array}$ & \multirow[t]{2}{*}{ P-Value } \\
\hline & nI (\%) & nI (\%) & n (\%) & \\
\hline \multicolumn{5}{|l|}{ Age groups } \\
\hline \multicolumn{5}{|l|}{ Religion } \\
\hline Muslim & $3(13)$ & $5(7.2)$ & $8(8.7)$ & \multirow{3}{*}{0.3992} \\
\hline Christian & $20(87)$ & $63(91.3)$ & $83(90.2)$ & \\
\hline Animist & $0(0)$ & I (I.4) & $\mathrm{I}(\mathrm{I} . \mathrm{I})$ & \\
\hline \multicolumn{5}{|l|}{ Parity (classes) } \\
\hline Pprimiparous & $16(69.6)$ & $33(47.8)$ & $49(53.3)$ & \multirow{3}{*}{0.0573} \\
\hline Pauciparous & $6(26.1)$ & $27(39.1)$ & $33(35.9)$ & \\
\hline Multiparous & I (4.3) & $9(13)$ & $10(10.9)$ & \\
\hline
\end{tabular}

Table 2 Characteristics of the causal pregnancy according to fistula location

\begin{tabular}{|c|c|c|c|c|}
\hline \multirow[b]{2}{*}{ Characteristics } & \multicolumn{3}{|c|}{ Fistula with urethral location } & \multirow[b]{2}{*}{ P-Value } \\
\hline & $\begin{array}{l}\text { Yes } \\
\text { NI=23 } \\
\text { nI (\%) }\end{array}$ & $\begin{array}{l}\text { No } \\
\text { N2=69 } \\
\text { n2 (\%) }\end{array}$ & $\begin{array}{l}\text { Total } \\
\text { N=92 } \\
\text { n (\%) }\end{array}$ & \\
\hline \multicolumn{5}{|l|}{ Number of ANC } \\
\hline No ANC & I (4.3) & $4(5.8)$ & $5(5.4)$ & \multirow{3}{*}{0.794} \\
\hline I-3 ANC & $16(69.6)$ & $43(62.3)$ & $59(64.2)$ & \\
\hline$\geq 4$ ANC & $6(26.1)$ & 22 (31.9) & $28(30.4)$ & \\
\hline \multicolumn{5}{|l|}{ Dystocia } \\
\hline Yes & $21(9 \mid .3)$ & $51(74)$ & $72(78.3)$ & \multirow{2}{*}{0.0663} \\
\hline No & $2(8.7)$ & $18(26.1)$ & $20(21.7)$ & \\
\hline \multicolumn{5}{|c|}{ Instrumental maneuvers } \\
\hline Yes & I (4.3) & $2(2.9)$ & $3(3.3)$ & \multirow{2}{*}{ I } \\
\hline No & $22(95.7)$ & $67(97.1)$ & $89(96.7)$ & \\
\hline \multicolumn{5}{|l|}{ Mode of delivery } \\
\hline Vaginal & I 8 (78.3) & $34(49.3)$ & $42(56.5)$ & \multirow{2}{*}{0.0167} \\
\hline Non vaginal & $5(21.74)$ & $35(50.72)$ & $40(43.5)$ & \\
\hline \multicolumn{5}{|l|}{ State of the child } \\
\hline Living & I (4.35) & $20(28.99)$ & $21(22.83)$ & \multirow{2}{*}{0.019} \\
\hline Deceased & $22(95.6)$ & 49 (7I.0I) & 7I (77.17) & \\
\hline
\end{tabular}

$\mathrm{N}$ : Size of study population, percentage $\%$

Low antenatal care (ANC) attendance $(\leq 2 \mathrm{ANC})$ was common in the two study populations $(69.5 \%)$. Dystocia was the most common among the subjects $(91.3 \%$ versus $73.9 \%)$. Perinatal death was more frequent urethral involvement group $(95.6 \%$ vs $71.01 \%$; OR: 8.97 ; $95 \%$ CI [1.13 to 71.19$] ; \mathrm{P}=0.019$ ) (Table 2) (Table 3). The size of the fistula was more frequent among subjects compared to the control, from 2 to $4 \mathrm{~cm}(61 \%$ vs. $23 \%)$; greater than $4 \mathrm{~cm}(30 \%$ vs. $10 \%)$. More subject's cases had already experienced at least one unsatisfactory surgical attempt (69.5\% vs $17.4 \%)$. During the intervention, episiotomy was much more practiced in subjects compared to controls $(73.9 \%$ vs $36.2 \%)$. Fistuloplasty was much more performed in fistula 
with urethral location (52.2 vs. 17.4) (Table 4-5). At discharge, closure with continence was lower among the urethral location cases $(95.6 \%$ vs. $42.2 \%$ ) and similar trend was found from three to Twelve months
( $81.2 \%$ vs $30.4 \%)$. Thus, urethral location cases were 10 times more likely to fail compared to their counterparts (OR: 9.84; 95\% CI [28.8 $3.36-] ;=0.000014$ ) (Table 6).

Table 3 Association between delivery characteristics and fistula location

\begin{tabular}{|c|c|c|c|c|c|}
\hline \multirow{3}{*}{ Characteristics } & \multicolumn{5}{|c|}{ Fistula with urethral location } \\
\hline & $\begin{array}{l}\text { Yes } \\
\text { NI=23 }\end{array}$ & $\begin{array}{l}\text { No } \\
\text { N2=69 }\end{array}$ & $\begin{array}{l}\text { Total } \\
\mathrm{N}=92\end{array}$ & Odds ratio $(95 \% \mathrm{Cl})$ & P-Value \\
\hline & n I (\%) & n2 (\%) & n (\%) & & \\
\hline \multicolumn{6}{|l|}{ Mode of Delivery } \\
\hline Vaginal & I8 (78.3) & $34(49.3)$ & $42(56.5)$ & $3.7(1.23-11.1)$ & 0.0167 \\
\hline Non vaginal & $5(21.74)$ & $35(50.72)$ & $40(43.5)$ & & \\
\hline \multicolumn{6}{|c|}{ Outcome of the child } \\
\hline Deceased & $22(95.6)$ & 49 (7I.0I) & 7I (77.17) & 8.97 (1.13-7I.19) & 0.019 \\
\hline Living & I (4.35) & $20(28.99)$ & $21(22.83)$ & & \\
\hline
\end{tabular}

N: Size of the study population, percentage\%

Table 4 Distribution of fistula location according to anatomic characteristics

\begin{tabular}{|c|c|c|}
\hline \multirow{4}{*}{ Characteristics } & \multicolumn{2}{|c|}{ Fistula with urethral location } \\
\hline & & No \\
\hline & $\mathrm{NI}=\mathbf{2 3}$ & N2=69 \\
\hline & nI (\%) & nI (\%) \\
\hline \multicolumn{3}{|l|}{ Vulva dermatitis } \\
\hline Yes & $15(65.2)$ & $29(42)$ \\
\hline No & $8(34.8)$ & $40(58)$ \\
\hline \multicolumn{3}{|c|}{ Location of fistula } \\
\hline Urethro-vaginal & $23(100)$ & $0(0)$ \\
\hline Cervico-vaginal & $0(0)$ & $10(14.5)$ \\
\hline Trigono-vaginal & $0(0)$ & $32(46.4)$ \\
\hline Retro-trigonal & $0(0)$ & $13(18.8)$ \\
\hline Juxta-cervical & $0(0)$ & $14(20.3)$ \\
\hline \multicolumn{3}{|c|}{ Size of fistula $(\mathrm{cm})$} \\
\hline$<2$ & $2(9.0)$ & $46(67.0)$ \\
\hline $2-4$ & $14(6 \mid .0)$ & $16(23.0)$ \\
\hline$>4$ & $7(30.0)$ & $7(10.0)$ \\
\hline \multicolumn{3}{|l|}{ Vaginal fibrosis } \\
\hline No & $7(30.5)$ & $56(8 I)$ \\
\hline Moderate & $7(30.5)$ & II (I6) \\
\hline Major & $9(39.0)$ & $2(3.0)$ \\
\hline
\end{tabular}

$\mathrm{N}$ : Size of the study population, percentage $\%$
Table 5 Association between therapeutic characteristics and fistula location

\begin{tabular}{|c|c|c|c|c|c|}
\hline \multirow{3}{*}{ Characteristics } & \multicolumn{4}{|c|}{$\begin{array}{l}\text { Fistula with urethral } \\
\text { location }\end{array}$} & \\
\hline & $\begin{array}{l}\text { Yes } \\
\text { NI=23 }\end{array}$ & $\begin{array}{l}\text { No } \\
\text { N2=69 }\end{array}$ & $\begin{array}{l}\text { Total } \\
\mathbf{N}=92\end{array}$ & $\begin{array}{l}\text { Odds } \\
\text { Ratio } \\
(95 \%)\end{array}$ & P-Value \\
\hline & n I (\%) & n2 (\%) & n (\%) & & \\
\hline
\end{tabular}

Surgical attempts

$\begin{array}{llllll}\text { More than one } & 16 & 12 & 28 & 11.11 & \\ & (69.5) & (17.4) & (30.4) & \begin{array}{l}(5.00- \\ 33.3)\end{array} & 0.000007 \\ & & & & \\ \text { I time } & 7(30.5) & 57 & 64 & \\ & & (82.6) & (69.6) & \end{array}$

Episiotomy

$\begin{array}{lllll} & & & 4.98 \\ & 17 & 25 & 42 & (1.74- \\ & (73.9) & (36.2) & (45.7) & 14.28) \\ & & & & \\ \text { No } & 6(26.1) & 44 & 50 & \\ & & (63.8) & (54.3)\end{array}$

0.003

Repair technique

$\begin{array}{llllll} & & & & 10.85 & \\ \text { Fistuloplasty } & 12 & 12 & 24 & (3.67- & 0.000003 \\ & (52.2) & (17.4) & (26.1) & 32.11) & \\ & & & & & \\ \text { Fistulorraphy } & \mathrm{II} & 57 & 68 & & \end{array}$


Table 6 Monitoring of urinary continence

\begin{tabular}{|c|c|c|c|c|c|}
\hline \multirow[b]{2}{*}{ Time since surgery } & \multicolumn{3}{|c|}{ Fistula with urethral involvement } & \multirow[b]{2}{*}{ Odds ratio $(95 \% \mathrm{Cl})$} & \multirow[b]{2}{*}{ P-Value } \\
\hline & $\begin{array}{l}\text { Yes } \\
\text { NI=23 } \\
\text { nI (\%) }\end{array}$ & $\begin{array}{l}\text { No } \\
\text { N2=69 } \\
\text { n2 (\%) }\end{array}$ & $\begin{array}{l}\text { Total } \\
\mathrm{N}=92 \\
\mathrm{n}(\%)\end{array}$ & & \\
\hline \multicolumn{6}{|c|}{ When discharged from hospital } \\
\hline $\begin{array}{l}\text { Yes } \\
\text { No }\end{array}$ & $\begin{array}{l}\text { I2(52.2) } \\
\text { I I (47.8) }\end{array}$ & $\begin{array}{l}66(95.6) \\
3(4.35)\end{array}$ & $\begin{array}{l}78(84.7) \\
\mid 4(\mid 5.2)\end{array}$ & $20(4.88-83.2)$ & 0.000005 \\
\hline \multicolumn{6}{|l|}{ At 3 months } \\
\hline $\begin{array}{l}\text { Yes } \\
\text { No }\end{array}$ & $\begin{array}{l}7(30.4) \\
16(69.6)\end{array}$ & $\begin{array}{l}56(81.2) \\
13(18.8)\end{array}$ & $\begin{array}{l}63(68.5) \\
29(31.5)\end{array}$ & $9.84(3.36-28.8)$ & 0.000014 \\
\hline \multicolumn{6}{|l|}{ At 6 months } \\
\hline Yes & $7(30.4)$ & $56(81.2)$ & $63(68.5)$ & & \\
\hline No & $16(69.6)$ & I3(18.8) & $29(31.5)$ & & \\
\hline \multicolumn{6}{|l|}{ At 12 months } \\
\hline Yes & $7(30.4)$ & $56(81.2)$ & $63(68.5)$ & & \\
\hline No & $16(69.6)$ & $13(18.8)$ & $29(31.5)$ & & \\
\hline
\end{tabular}

$\mathrm{N}$ : Size of the study population, percentage \%

\section{Discussion}

The average age in both study groups was $26 \pm 8.02$ years, similar to reports from Africa and Asia with the mean age at treatment around 25-29. ${ }^{22-24}$ Proportion of unmarried women $(65.2 \%)$ was higher than that of 40 to $50 \%$ reported by others. ${ }^{25,26}$ The majority of patients in both study populations had primary level of education $(54.3 \%)$. Many studies reported high illiteracy rate among fistula patients (50 to $96 \%) .{ }^{27-29}$ Housewife status was high (77.2\%) as reporter by other. ${ }^{25,30}$ Almost half of the participants were primiparous (53\%) and lower than 60 to $86 \%$ reported in many studies. ${ }^{5,31,32}$ More than half of the patients had done less than 3 ANC (69.5\%). Other studies reported up to $92 \%$ of fistula patients without any ANC attendance. ${ }^{27,28,33}$ This condition can be the consequence of illiteracy, ignorance and inadequate health education.

Labor duration of 24 to 48 hours in the indexed pregnancy (52.1\%) was lower to those from many others who reported a proportion of up to $96 \%$ of prolong labor. ${ }^{21,34-36}$ Dystocia was common in the subject group $(91.3 \%$ Vs. $73,9 \%)$ and underscore the causal value of prolonged compression of the fetal head on soft tissue leading to necrosis. Higher proportion of perinatal mortality was reported in subjects group ( $95.65 \%$ vs $71.01 \%$ ) as already reported by others (up to $96 \%$ ) in fistula patients..$^{21,36,37}$ Surgical failure at first attempt was more common among patients with urethral involvement $(69.5 \%$ vs 17.4\%; OR: $11.11 ; 95 \%$ CI [5.0-33], $\mathrm{P}=0.000007)$. In Nigeria, $66 \%$ of fistula patients had already undergone at least one surgical attempt. ${ }^{38}$ This observation could be due to the urethral location as a predictor for poor prognosis. In a Guinean study, $43 \%$ of patients experience at least two surgical attempts. ${ }^{39}$ Fistula with urethral involvement was 10-times more likely to have an undue vaginal condition (sclerotic) than controls (69.6\% Vs.18.8\%; OR: 9.84; 95\% CI [3, 31 to 28.81] $\mathrm{P}=0.000014$ ). Many studies report fibrotic status of genitourinary fistula up to $20.5 \%$ in the DRC, $64.9 \%$ in Uganda and $70.4 \%$ in Nigeria. ${ }^{19,22,40}$ This condition affects the prognosis of fistula surgery as limiting factor for tissue dissection. This sclerotic nature can be the consequence of previous surgical attempts that increase the risk of vaginal fibrosis. The fistula size of $2-4 \mathrm{~cm}$ was more frequent among subjects compared to the control (61\% vs. $23 \%)$; greater than $4 \mathrm{~cm}$ $(30 \%$ vs. $10 \%)$. Many studies reported large sizes of genitourinary fistula. In Kenya, authors report that 15 of 31 genitourinary fistulas had a size of more than $2 \mathrm{~cm} .{ }^{12}$ We found no study analysing the size of the fistula in case of urethral involvement or not.

Regarding the repair technique, fistuloplasty was performed 5 folds for urethral involvement (52.2\% vs. $17.4 \%$; OR: $5.18 ; 95 \%$ CI [1.85 to 14.48] $\mathrm{P}=0.002$ ). This observation is explained as in some cases used the Martius methods of turning scraps of the vagina and/or the labia minora and the interposition of fatty cellular tissue as suggested by some author. ${ }^{41,42}$ At discharge, patients with urethral involvement were more likely to have a leaking flow than controls (47.8\%) vs $4.35 \%$; OR: 20; 95\% CI $[4,88-83] \mathrm{P}=0.000005)$. This observation suggests a satisfaction rate of $52.2 \%$ for subjects and $95.65 \%$ for control. This result reveals a bad early prognosis in case of fistulas with urethral involvement.

From 3 to 12 months after surgery, patient satisfaction was $30.4 \%$ in subjects and $81.2 \%$ in controls. The difference in outcome observed in urethral involvement is similar to the report from others. ${ }^{21,43} \mathrm{In}$ India, success was reported for 3/4 and 30/34 (94\%) of urethro vaginal and vesico-vaginal fistula respectively. ${ }^{43}$ Success rate of $57 \%$ and $79 \%$ in case of cervico-urethral and bladder involvement was reported by Arrowsmith. ${ }^{21}$ Concerning pure result of urethral fistula, mostly small case series have been reported, in India, authors reported the reconstruction of seven urethra with satisfaction and emphasize on the value of Martius graft which they used. ${ }^{41}$ In an Erithrean's report, 
urethral location did not affect the prognosis as 10 out of 13 patients had good result. ${ }^{44}$ Among 37 fistulas with urethral involvement in Mali, satisfaction of $48.4 \%$ was reported. ${ }^{45}$ Other authors reported the results of urethral reconstruction from advancement of vaginal flap of the posterior wall of the bladder with reconstruction of the bladder neck with satisfaction of 14/18 (70\%). A urethral reconstruction with tabulated vaginal flap without Martius transplant was recently reported with satisfaction of $86.0 \%{ }^{46}$

Poor satisfactory among fistulas with urethral involvement may be due to multiple operations, in Ghana. total satisfaction was $85 \%$ at the first operation, $50 \%$ at the second and 33\% at the third. ${ }^{16}$ In Zambia, an overall satisfaction of $59.1 \%$ was reported with $70 \%, 18 \%$ and $11 \% .{ }^{17}$ The previous surgery acts as proxi-factor promoting the fibrosis and enlargement of fistula. The importance of urethral destruction impact on the surgical prognosis. Kishner et al., ${ }^{47}$ reported a satisfaction at discharge according to the urethral status at $(92.4 \%)$ when intact, $(47.4 \%)$ if partial destruction and (21.2\%) if total destruction. ${ }^{47}$

\section{Conclusion}

Genitourinary obstetric fistulas without urethral involvement have better chance of closure with continence $(81.2 \%)$ compared to genitourinary obstetric fistula with urethral damage (30.4\%).

\section{Acknowledgments}

The research team is extremely grateful for the collaboration of the University Teaching Hospital, Yaoundé.

\section{Conflicts of interest}

Author has no conflict of interest to declare.

\section{References}

1. Tebeu PM, Boisrond L, Boisrond L, et al. Knowledge, attitude and perception about obstetric fistula by Cameroonian women. Prog Urol. 2008;18(6):379-389.

2. Muleta M. Obstetric fistulae: a retrospective study of 1210 cases at the Addis Ababa Fistula Hospital. J Obstet Gynaecol. 1997;7(1):68-70.

3. Falandry L. VVF in Africa, 230 observations. Presse Med. 1992;21(6):241245.

4. Gueye SM, Ba M, Sylla C, et al. Mensah vesicovaginal fistulas, etio-pathogenic and therapeutic aspects in Senegal. Afr Med $N$. 2008;39(8/9):559-563.

5. Zoung Kanyi-J, Sow M. focus on vesicovaginal fistulas at the Yaounde Central Hospital. Apropos of 111 cases seen in 10 years. Ann Urol (Paris). 1990;24(6):457-461.

6. Browning A. Obstetric fistula: current and future practicalities concerns Int J Pelvic Floor Urogynecol Dysfunct. 2008;19(3):333-334.

7. Tebeu PM, Kemfang Ngowa JD, Noa Ndoua C, et al. Causes of obstetric fistula genito-urinary: an experience from the University Hospital, Yaounde, Cameroon. Int J Curr Res. 2015;7(9):20589-20593.

8. Tebeu PM, Fomulu JN, Khaddaj S, et al. Risk factors for obstetric fistula: a clinical review. Urogynecol Int J. 2012;23(4):387-394.

9. Gray PH. Obstetric vesicovaginal fistulas. Am J Obstet Gynecol. 1970;107(6):898-901.

10. Goh J, Stanford EJ, Genadry R. Classification of female genito-urinary tract fistula: a comprehensive review. Urogynecol Int $J$ Pelvic Floor Dysfunct. 2009;20(5):605-610.

11. Chelli D, Boudaya F, Hammedi N, et al. The VVF of obstetric origin: about 131 cases. Tunis Med. 2010;88(6):414-419.

12. McFadden E, Taleski SJ, Bocking A, et al. Retrospective review of predisposing factors and surgical outcomes in obstetric fistula patients at a single teaching hospital in Western Kenya. J Obstet Gynaecol Can. 2011;3(1):30-35.

13. Uprety DK, Subedi S, Budhathoki B, et al. Vesicovaginal fistula at tertiary care center in eastern Nepal. J Med Assoc JNMA Nepal. 2008;47(171):120-122.

14. Wadie BS, Kamal MM. Repair of vesicovaginal fistula: Single center experience and analysis of outcome predictors. Arab J Urol. 2011;9(2):135-138

15. Bernis L. Obstetric fistula: guiding principles for clinical management and development program, new WHO guideline. Int J Obstet Gynaecol. 2007;99 Suppl 1:S117-S121.

16. Elkins TE. Surgery for the obstetric vesicovaginal fistula: a review of 100 operations in 82 patients. Am J Obstet Gynecol. 1994;170(4):1108-1118.

17. Wadhawan S, Wacha DS. A review of urinary fistulae in a university teaching hospital. Int J Gynaecol Obstet. 1983;21(5):381-385.

18. Tebeu PM. Impact of the recurrence on the surgical outcome of women operated for obstetric vesico-vaginal fistula: a Cameroonian experience. 4th ISOFS Congress 2012, Dhaka, Bangladesh: Abstract book; 2012.

19. Kayondo M, Wasswa S, Kabakyenga J, et al. Predictors and outcome of surgical repair of obstetric fistula at a regional referral hospital, Mbarara, western Uganda. BMC Urol. 2011;11:23.

20. Tebeu PM, Fomulu JN, Mbassi AA, et al. Quality Care in Vesico-Vaginal Fistula: case series carryover from the Regional Hospital Maroua, Cameroon. Pan Afr Med J. 2010;5:6.

21. Arrowsmith SD. Genitourinary Reconstruction in obstetric fistulas. $J$ Urol. 1994;152(2 Pt 1):403-406.

22. Loposso M, Hakim L, Ndundu J, et al. Predictors of recurrence following treatment and successful obstetric fistula surgery. Urology. 2016;97:8085 .

23. Sori DA, Azale AW, Gemeda DH. Characteristics and outcome of patients with repair fistula Vesicovaginal managed in Jimma University teaching Hospital, Ethiopia. BMC Urol. 2016;16(1):41.

24. Priyadarshi V, JP Singh, Bera MK, et al. Genitourinary Fistula: An Indian Perspective. J Obstet Gynaecol India. 2016;66(3):180-184.

25. Tebeu PM, de Bernis L, Doh AS, et al. Risk factors for obstetric fistula in the Far North Province of Cameroon. Int $J$ Gynaecol Obstet. 2009;107(1):12-15.

26. Drew LB, JP Wilkinson, Nundwe W, et al. Long-term outcomes for women after-obstetric fistula repair in Lilongwe, Malawi: a qualitative study. BMC Pregnancy Childbirth. 2016;16:2.

27. Jokhio AH, Kelly J. Obstetric fistulas in rural Pakistan. Int J Gynaecol Obstet. 2006;95(3):288-289.

28. Gessessew A, Mesfin M. Genitourinary and rectovaginal fistulae in Adigrat Zonal Hospital, Tigray, Ethiopia north. Ethiop Med J. 2003;41(2):123130.

29. Ijaiya MA, Aboyeji PA. Obstetric urogenital fistula: the experience Ilorin, Nigeria. West Afr J Med. 2004;23(1):7-9. 
30. Aristide KF, Kambou T, Ouattara A, et al. Epidemiology, etiology and psychosocial impact of urogenital fistulas in a cohort of 170 consecutive patients managed in three treatment centers in Burkina Faso from 2010 to 2012. Prog Urol. 2014;24(8):526-532.

31. Umoiyoho AJ, Inyang Etoh-EC, Etukumana EA. Obstetric fistula repair: experience with hospital-based outreach approach in Nigeria. Glob $J$ Health Sci. 2012;4(5):40-45.

32. Harouna YD, Seidou A, Maikano S, et al. The VVF obstetric causes: Survey 52 women admitted to the village with fistula. Afr Med Black. 2001;48(2):55-59.

33. Melah GS, Massa AA, Yahaya UR, et al. Risk factors for obstetric fistulae in north-eastern Nigeria. J Obstet Gynaecol. 2007;27(8):819-823.

34. Nafiou I, Idrissa A, Ghaichatou AK, et al. Obstetric vesico-vaginal fistulas at the National Hospital of Niamey, Niger. Int J Obstet Gynaecol. 2007;99 Suppl 1:S71-S74.

35. Holme A, Breen M, MacArthur C, Obstetric fistulae: a study of women managed at the Monze Mission Hospital, Zambia. BJOG. 2007;114(8):1010-1017.

36. Hilton P, Ward A. Epidemiological and surgical aspects of urogenital fistulae: a review of 25 years' experience in southeast Nigeria. Urogynecol Int J Pelvic Floor Dysfunct. 1998;9(4):189-194.

37. Wall LL, Karshima JA, Kirschner C, et al. The obstetric vesicovaginal fistula: characteristics of 899 patients from Jos, Nigeria. Am J Obstet Gynecol. 2004;190(4):1011-1019.

38. Karateke A, Cam C, Ozdemir A, et al. Characteristics of obstetric fistulas and the need for a prognostic classification system. Arch Med Sci. 2010;6(2):253-256.
39. Delamou A, Utz B, Delvaux T, et al. Pregnancy and childbirth after-repair of obstetric fistula in sub-Saharan Africa: scoping review. Trop Med Int Health. 2016;21(11):1348-1365.

40. Kirschner CV, Yost KJ, From H, et al. Obstetric fistula: the ECWA Evangel VVF Center surgical experience from Jos, Nigeria. Urogynecol Int J. 2010;21(12):1525-1533.

41. Rangnekar NP, Imdad AN, Kaul SA, et al. Role of the Martius procedure in the management of urinary-vaginal fistulas. $J$ Am Coll Surg. 2000;191(3):259-263.

42. Falandry L. Double autoplasty of the labium majus in the surgical repair of vesicovaginal fistula rectovaginal of obstetric origin. A presentation of 17 cases. J Chir (Paris). 1990;127(2):107-112.

43. Mathur R, Joshi N, Aggarwal G, et al. Urogenital fistulae: A prospective study of 50 cases at a tertiary care hospital. Ann Urol (Paris). 2010;2(2):67-70

44. Husain A, Johnson K, Glowacki CA, et al. Surgical management of complex obstetric fistula in Eritrea. J Womens Health (Larchmt) 2005;14(9):839-844.

45. Ouattara K, Traore ML, Cisse C. Treatment of African VVF in Mali. Experience of Urology Hospital of the point "G" Bamako. About 134 cases. Afr Med Black. 1991;38:863-866.

46. Sawant A, Kasat GV, Kumar V, et al. Reconstruction of female urethra with tubularized anterior vaginal flap. J Clin Diagn Res. 2016;10(7):C01C03.

47. Kirschner CV, Yost KJ, From H, et al. Obstetric fistula: the ECWA Evangel VVF Center surgical experience from Jos, Nigeria. Urogynecol Int J. 2010;21(12):1525-1533. 